\title{
Journal of

\section{The generation of palladium silicide nanoalloy particles in a SiCN matrix and their catalytic applications}

\author{
Muhammad Zaheer, ${ }^{a}$ Günter Motz ${ }^{* b}$ and Rhett Kempe ${ }^{* a}$ \\ Received 1st August 2011, Accepted 23rd September 2011 \\ DOI: 10.1039/c1jm13665h
}

\begin{abstract}
The synthesis, characterization and catalytic studies of single phase palladium silicide nanoalloy particles supported by a polymer derived, non-oxide SiCN matrix $\left(\mathrm{Pd}_{2} \mathrm{Si} @ \mathrm{SiCN}\right)$ are reported. Simultaneous chemical modification of a polyorganosilazane as well as its cross-linking was achieved by the use of an aminopyridinato palladium complex at room temperature. Cross-linking takes place with an evolution of hydrogen and increases the ceramic yield by the retention of carbon and nitrogen atoms. Liberation of ligand, as confirmed by ${ }^{1} \mathrm{H}$ NMR spectroscopy, provides indirect evidence of the transfer of palladium to the nitrogen functions producing metal modified polyorganosilazane whose pyrolysis at $1100{ }^{\circ} \mathrm{C}$ under nitrogen atmosphere provides $\mathrm{Pd}_{2} \mathrm{Si} @ \mathrm{SiCN}$. Powder X-ray diffraction (PXRD) studies confirmed the presence of the hexagonal $\mathrm{Pd}_{2} \mathrm{Si}$ phase in the amorphous $\mathrm{SiCN}$ matrix. The size of the particles formed seems to depend upon the nature of the solvent used in the cross-linking step. The amount of palladium complex added seems not to affect the size of particles formed but does increase their population density. $\mathrm{Pd}_{2} \mathrm{Si} @ \mathrm{SiCN}$ catalysts were found active for the hydrogenation of ketones. The selectivity of the reaction towards the alcoholic product remains very high. The conversion of the reaction however decreases both with increase in alkyl chain length as well as its branching at alpha carbon. The recyclable $\mathrm{Pd}_{2} \mathrm{Si} @ \mathrm{SiCN}$ could be a suitable choice for catalytic transformations under a harsh chemical environment and at higher temperatures.
\end{abstract}

\section{Introduction}

Nanoalloys, owing to their improved structural, electronic and optoelectronic properties as compared to their (metallic) counterparts, find intensive applications in many areas of technological importance. ${ }^{1}$ For instance, bimetallic alloy nanoparticles have been applied in light emitting diodes (LEDs), ${ }^{2,3}$ data storage devices, ${ }^{4,5}$ and thermoelectric devices. ${ }^{6} \mathrm{~A}$ salient feature of nanoalloy particles is the superior catalytic performance and their applications, in this regard, range from electrochemical fuel cell reactions ${ }^{7-12}$ to various oxidation reactions ${ }^{13-16}$ and renewable energy production..$^{17,18}$ Polymer derived ceramics (PDCs) have been investigated intensively in the past two decades. ${ }^{19}$ PDCs based on the SiCN ternary system are highly robust materials possessing extraordinary high temperature properties $\mathrm{s}^{20,21}$ and oxidation resistance up to $1600^{\circ} \mathrm{C}^{22}$ without showing any prominent mechanical creep. ${ }^{23}$ On the account of their polymer route synthesis, fabrication of fibers, ${ }^{24}$ films ${ }^{25}$ and coatings ${ }^{26}$ is facilitated. Introduction of metal not only improves the electrical, ${ }^{27}$ thermal, and magnetic properties ${ }^{28}$ of these materials but also extends their application profile to catalysis,

${ }^{a}$ Inorganic Chemistry II, University of Bayreuth, 95440 Bayreuth, Germany.E-mail:kempe@uni-bayreuth.de

${ }^{b}$ Ceramic Materials Engineering, University of Bayreuth, 95447 Bayreuth, Germany.E-mail: guenter.motz@uni-bayreuth.de where such robust systems have successfully been used as catalysts for fuel reforming, ${ }^{29}$ total oxidation of methane ${ }^{30}$ and the decomposition of ammonia. ${ }^{31}$ In addition, metal containing $\mathrm{SiCN}$ ceramics have been reported to be selective catalysts in the oxidation of alkanes using air as an oxidant. ${ }^{32}$ The synthetic strategies for metal containing polymer derived ceramics can broadly be divided into three categories. Firstly, the chemical modification of organosilicon polymers by the use of metal powders ${ }^{33}$ or by metal oxides ${ }^{34}$ secondly, modification at a molecular level by the use of metal complexes ${ }^{35,36}$ followed by its pyrolysis to obtain metal containing ceramics. The third approach makes use of metal containing organosilicon polymers ${ }^{37-40}$ and their subsequent ceramization. We recently reported a molecular approach utilizing aminopyridinato transition metal complexes for the chemical modification of polyorganosilazane $^{41,32}$ (HTT 1800) whose pyrolysis provided metal particles containing SiCN ceramics. This synthetic protocol is advantageous in the sense that it avoids entry of any foreign element as the aminopyridinato complexes contain the same elements as contained by the polysilazane. Such complexes can be synthesized in good yields and are available for almost all the transition elements. ${ }^{42}$ Moreover, the dispersion of metal within the ceramic is assured owing to the covalent linkages of metal with the nitrogen functionalities of the polysilazane. This molecular approach for the synthesis of metal containing SiCN ceramics is (here) extended to the synthesis of so-called intermetallic nanoparticles (nanoalloys). 
The aminopyridinato complex of palladium used here generates palladium silicide nanoparticles by the chemical modification of the polysilazane. Moreover, it cross-links the polymer efficiently at room temperature increasing the ceramic yield by the retention of carbon and nitrogen atoms within the ceramic. Conventional synthesis of palladium silicides involves the annealing of palladium on silicon substrates which, depending upon the stoichiometric ratio and annealing temperature, generates different silicide phases $\left(\mathrm{Pd}_{x} \mathrm{Si}_{y}\right) .{ }^{43}$ Although the growth and structure of palladium silicide have been studied extensively in the past, there are only a few reports on the nanosizing of palladium silicides. ${ }^{44}$ Here we report on the synthesis of palladium silicide nanoparticles and their size control within a $\mathrm{SiCN}$ support and their catalytic applications.

\section{Experimental}

\section{General remarks}

All reactions were carried out under dry argon using standard Schlenk and glove box techniques. Solvents were dried and distilled from sodium benzophenone before use. Deuterated solvents obtained from Cambridge Isotope Laboratories were degassed, dried using molecular sieves and distilled prior to use. n-Butyllithium, 2-amino-4-picoline, chlorotrimethylsilane, acetophenone (ACROS Chemicals), dichloroplatinum(II) (Alfa Aesar) and polysilazane (HTT 1800, Clariant, GmbH) were used as received without any further purification.

\section{Ligand and complex synthesis}

The starting material 4-methyl-2-((trimethylsilyl)amino)pyridine $1,{ }^{45}$ dichloro(1,5-cyclooctadiene)platinum(II) ${ }^{46}$ and complex $\mathbf{2}^{\mathbf{4 7}}$ were synthesized following reported methods (Fig. 1).

\section{Cross-linking, metal transfer and pyrolysis}

Polysilazane HTT 1800 (3.218 g) was reacted with palladium aminopyridinato complex 2 (Pd/Si 1/20, $1.16 \mathrm{~g}, 2.49 \mathrm{mmol} ; \mathrm{Pd} / \mathrm{Si}$ 1/40, $0.581 \mathrm{~g}, 1.25 \mathrm{mmol}$; Pd/Si 1/60, $0.38 \mathrm{~g}, 0.83 \mathrm{mmol} ; \mathrm{Pd} / \mathrm{Si}$

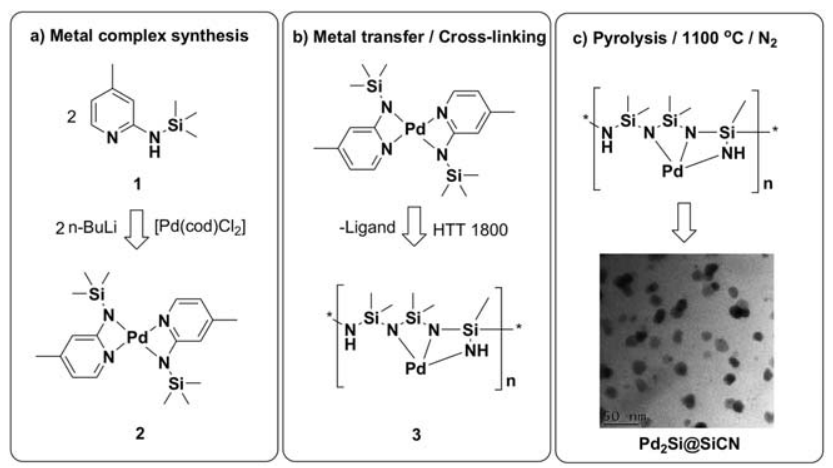

Fig. 1 Scheme for the synthesis of $\mathrm{Pd}_{2} \mathrm{Si}$ nanoparticles containing $\mathrm{SiCN}$ ceramics: (a) synthesis of complex $\mathbf{2}$ from ligand 1; (b) the polysilazane (HTT 1800) is chemically modified by its reaction with the complex along with the liberation of the ligand; (c) metal modified polysilazane $\mathbf{3}$ produces dipalladium silicide nanoparticles supported SiCN ceramics upon pyrolysis at $1100{ }^{\circ} \mathrm{C}$ under nitrogen atmosphere. $n$-BuLi: $n$-butyllithium; cod: 1,5-cyclooctadiene; HTT 1800: polyorganosilazane.
Table 1 Designation of the samples synthesized by using different amounts of palladium complex reacted with HTT 1800, respective palladium to silicon ratio and palladium loading in resulting ceramics

\begin{tabular}{lllll}
\hline & & & Pd loading $^{b}$ & \\
\cline { 5 - 5 } $\begin{array}{l}\text { Sample ID } \\
(\text { CL/FC) }\end{array}$ & $\begin{array}{l}\text { Pd complex } \\
\text { (wt\% HTT 1800) }\end{array}$ & $\begin{array}{l}\text { Pd/Si } \\
\text { (ratio) }\end{array}$ & Calculated & Measured \\
\hline Pd20 & 36.0 & $1 / 20$ & 8.17 & 6.91 \\
Pd40 & 18.0 & $1 / 40$ & 4.86 & 3.36 \\
Pd60 & 12.0 & $1 / 60$ & 3.32 & 2.50 \\
Pd80 & 9.0 & $1 / 80$ & 2.61 & 1.31 \\
Pd100 & 7.2 & $1 / 100$ & 2.09 & 0.74 \\
Pd1000 & 0.2 & $1 / 1000$ & 0.22 & -
\end{tabular}

${ }^{a}$ Suffixes CL and FC correspond to the cross-linked and ceramic form respectively. ${ }^{b}$ Palladium loading in $\mathrm{wt} \%$.

1/80, $0.29 \mathrm{~g}, 0.62 \mathrm{mmol}$; Pd/Si 1/100, $0.23 \mathrm{~g}, 0.5 \mathrm{mmol})$ in tetrahydrofuran (THF) (5 mL) (Table 1). No cross-linking agent was added as the complex itself acts as a cross-linking agent and changes the orange solution into a black solid. The solvent was evaporated under vacuum and the solid obtained was pyrolysed under nitrogen atmosphere at $1100{ }^{\circ} \mathrm{C}\left(5 \mathrm{~K} \mathrm{~min}^{-1}\right.$; holding time: $30 \mathrm{~min}$ ) to get the ceramics.

\section{Characterization}

Nuclear magnetic resonance (NMR) spectra were recorded using a Varian INNOVA 400 spectrometer. Chemical shifts are reported relative to deuterated solvent. Ceramisation was carried out under nitrogen in a high temperature furnace (Nabertherm LH 60/14, Nabertherm, Germany). Gas chromatography (GC) analyses were performed by using an Agilent 6890N gas chromatograph equipped with a flame ionization detector (FID) and an Agilent 19091 J-413 FS capillary column using dodecane as internal standard. All X-ray powder diffractograms were recorded by using a STOESTADI-P-diffractometer $\left(\mathrm{CuK}_{\alpha}\right.$ radiation, $1.54178 \AA$ ) in $\theta$-2 $\theta$-geometry and with a position sensitive detector. Transmission electron microscopy (TEM) was carried out by using a Varian LEO $9220(200 \mathrm{kV})$ instrument. The sample was suspended in chloroform and sonicated for $5 \mathrm{~min}$. Subsequently a drop of the suspended sample was placed on a grid (Plano S 166-3) and allowed to dry.

Elemental analysis was performed by standard protocols employing digestion in $\mathrm{HNO}_{3} / \mathrm{HCl} / \mathrm{H}_{2} \mathrm{O}_{2}$ and inductively coupled plasma optical emission spectrometry (ICP-OES) using a Varian, Vista-Pro radial. FT-IR measurements were performed using a Perkin-Elmer FTIR-Spectrum 100.

\section{Catalytic studies}

$1 \mathrm{mmol}$ of ketone in toluene $(0.4 \mathrm{~mL})$ was taken in a glass tube along with a magnetic bar and $60 \mathrm{mg}$ of milled ceramics (particle size: $<100 \mu \mathrm{m})$ was added. This tube was placed in a Parr autoclave under a hydrogen pressure of 40 bar. The reactor was heated to the respective temperature within $20 \mathrm{~min}$ and stirring (400 rpm) was continued at this temperature for 24 hours. Afterwards, reaction mixture was diluted with THF and dodecane as internal standard was added. The conversion and selectivity were determined by GC. 


\section{Results and discussion}

\section{Synthesis of palladium complex, metal modified polysilazane and} ceramics

Fig. 1 shows the schematic presentation of the synthesis of the palladium complex (Fig. 1a), chemical modification of $\mathrm{Si}-\mathrm{H}$ and vinyl-silicon groups containing HTT 1800 (Fig. 1b) and the generation of dipalladium silicide nanoparticles supported by SiCN ceramics (Fig. 1c). Polysilazane HTT 1800 was reacted with different amounts of palladium complex 2 (Table 1) to get the metal modified and cross-linked thermosets $\mathbf{3}$ whose pyrolysis at $1100{ }^{\circ} \mathrm{C}$ provided $\mathrm{Pd}_{2} \mathrm{Si} @ \mathrm{SiCN}$.

Complex 2 was reacted with polysilazane HTT 1800 in THF $(5 \mathrm{~mL})$. Upon mixing of the complex with polysilazane, an exothermic reaction takes place with effervescence and solution gradually changes its color until it completely converts into a black solid. The shape of the solid can be controlled by the amount of solvent added. With a relatively small amount of solvent more volume expansion and foaming were observed which could be avoided by the addition of more solvent. GC analysis of the gaseous products of the cross-linking reaction shows predominance of hydrogen.

The Seyferth group had reported on the dehydrocoupling between $\mathrm{Si}-\mathrm{H}$ bonds by the reaction of $\mathrm{Ru}_{3}(\mathrm{CO})_{12}$ with alkylsilyl hydrides. ${ }^{48}$ On the basis of hydrogen evolved during cross-linking we assume the same kind of dehydrocoupling between $\mathrm{Si}-\mathrm{H}$ functions (besides cross-linking via hydrosilylation and vinyl polymerization). ${ }^{49}$ FT-IR studies of the reaction of HTT 1800 with the palladium complex (Fig. 3) show the decrease in the intensities of the vibrations characteristic of vinylic (2998$\left.3084 \mathrm{~cm}^{-1}\right)$, Si-H $\left(2150 \mathrm{~cm}^{-1}\right)$ and N-H $\left(3300-3500 \mathrm{~cm}^{-1}\right)$ bonds. This supports the hydrosilylation and dehydrocoupling crosslinking mechanisms to be operative and the formation of $\mathrm{Pd}$ amides. Improved yields of the ceramics also support the
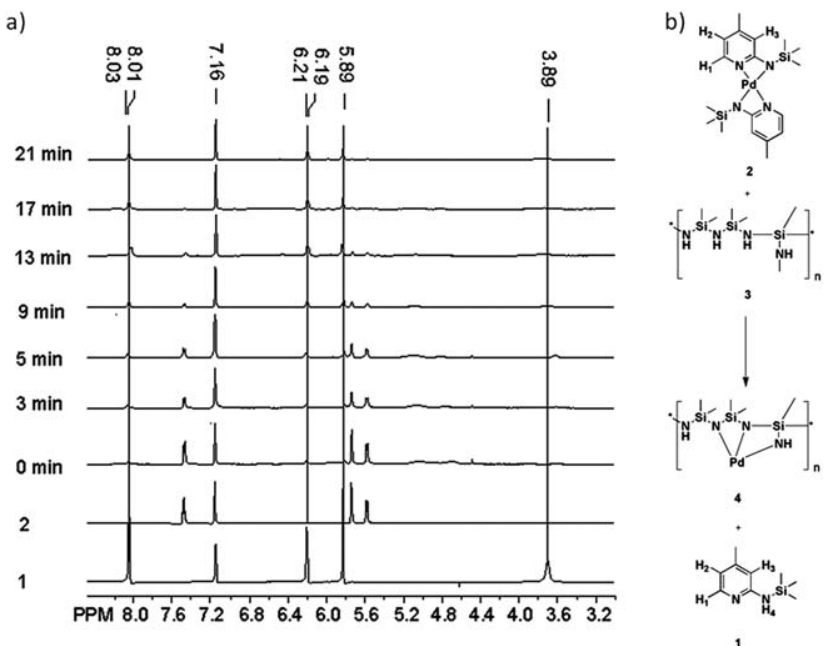

Fig. 2 (a) ${ }^{1} \mathrm{H}$ NMR spectra of the reaction mixture (HTT 1800 and complex 2 in benzene) at different time intervals; (b) schematic representation of metal transfer reaction which produces metal modified polysilazane (4) by the reaction of palladium aminopyridinato complex 2 with HTT 1800 3. The palladium is transferred to the nitrogen functions of the polymer with the liberation of protonated ligand $\mathbf{1}$.

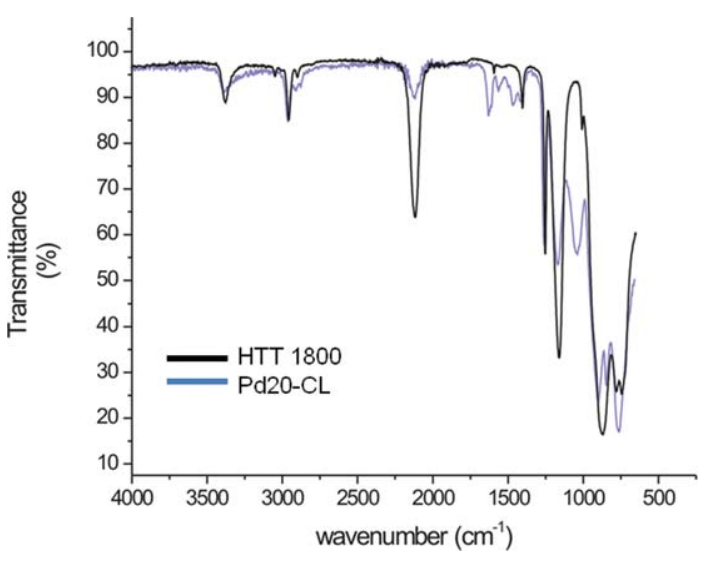

Fig. 3 FT-IR spectrum of HTT 1800 before and after the addition of complex. The decrease in the intensities of $\mathrm{Si}-\mathrm{H}$ and $\mathrm{CH}_{2}=\mathrm{CH}$ - vibrations was observed upon the addition of the palladium complex.

dehydrocoupling mechanism as it will result in the retention of carbon and nitrogen atoms within the ceramics. The use of free radical initiators for the initiation of cross-linking could be avoided by the use of the palladium aminopyridinato complex.

Kinetic studies of metal transfer reaction (cross-linking) were performed using ${ }^{1} \mathrm{H}$ NMR. HTT 1800 was reacted with complex 2 in deuterated benzene $\left(\mathrm{C}_{6} \mathrm{D}_{6}\right)$ and spectra were recorded after every 2 min (Fig. 2a). The characteristic signals of the complex gradually decrease in intensities until they are totally absent after 20 minutes of reaction time. At this time, the spectrum of the reaction mixture shows only the characteristic resonance signals of the ligand (Fig. 2a and b). Moreover resonance of the $-\mathrm{NH}-$ function, originally absent in the spectrum of the complex, again appears at $3.89 \mathrm{ppm}$ confirming the evolution of free protonated ligand in the reaction mixture. This liberation of ligand provides indirect evidence of the transfer of palladium to the nitrogen functions of polysilazane most probably due to the availability of more coordination sites in the polymer. Based upon aforementioned observations, it may be concluded that the palladium complex chemically modifies the polysilazane by coordination of palladium to its nitrogen atoms. The solvent free, metal modified and cross-linked polysilazane was then shifted to a furnace for pyrolysis.

\section{Pyrolysis and ceramization}

The metal modified cross-linked polymers were heated under nitrogen atmosphere in a furnace with a heating rate of $5 \mathrm{~K} \mathrm{~min}^{-1}$ up to $1100{ }^{\circ} \mathrm{C}$ to get an amorphous metal containing $\mathrm{SiCN}$ ceramics.

\section{Characterization of $\mathrm{Pd}_{2} \mathrm{Si} @ \mathrm{SiCN}$}

Thermogravimetric analysis (TGA). TGA analysis of the crosslinked precursors was carried out with a heating rate of $5 \mathrm{~K} \mathrm{~min}^{-1}$ up to $1100{ }^{\circ} \mathrm{C}$ under nitrogen atmosphere (Fig. 4). Major mass loss (21-26\%) occurs between 100 and $730{ }^{\circ} \mathrm{C}$ and may be attributed to the loss of gases (methane, ammonia and hydrogen). ${ }^{50}$ Above $730{ }^{\circ} \mathrm{C}$, the observed mass loss was only $1.2-$ $1.5 \%$ giving ceramic yields of $78 \%$ (Pd100-FC, curve b) and $73 \%$ (Pd20-FC, curve a). Theoretically speaking, a total yield of $65 \%$ 


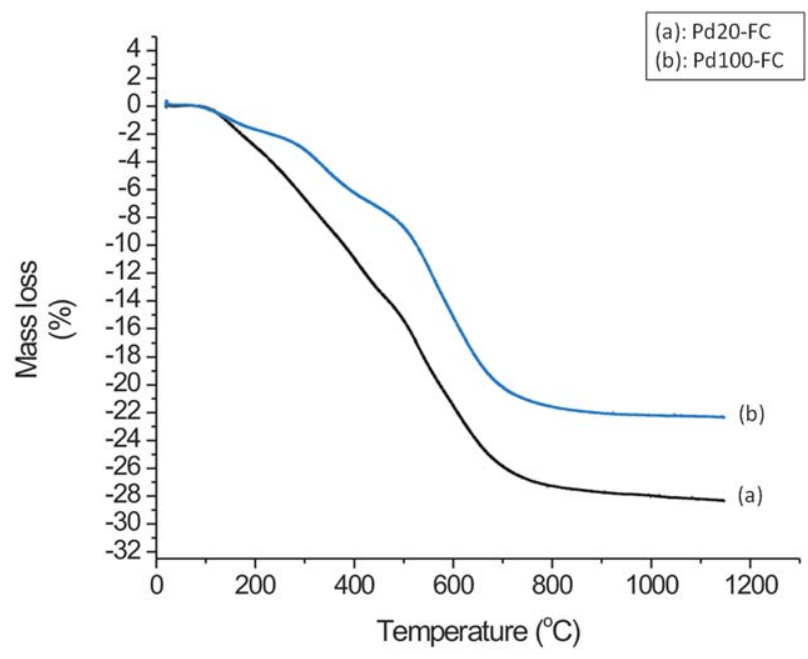

Fig. 4 TGA analysis of $\mathrm{Pd} 20-\mathrm{FC}(8 \mathrm{wt} \% \mathrm{Pd})$ in comparison with $\mathrm{Pd} 100-$ $\mathrm{FC} \mathrm{(2} \mathrm{wt} \% \mathrm{Pd}$ ); major mass loss occurs between 100 and $730{ }^{\circ} \mathrm{C}$ giving ceramic yields of $78 \%$ for Pd100-FC (b) and 73\% for Pd $20-\mathrm{FC}$ (a).

was expected in the case of Pd20-FC assuming the total loss of ligand and complete retention of palladium during ceramization. An increase in yield by $8 \%$ suggests that ligand is not totally lost during ceramization and contributes towards ceramic yield. This may be attributed to the retention of silicon and palladium atoms contained by the ligand during pyrolysis. Moreover, the evolution of hydrogen during cross-linking reaction suppresses the emission of methane and ammonia (at $300-500{ }^{\circ} \mathrm{C}$ ) gases resulting in the retention of carbon and nitrogen atoms. The loss of oligomers in the temperature regime of $100-300{ }^{\circ} \mathrm{C}$ is avoided owing to the efficient cross-linking of polysilazane by the palladium complex. It is evident from TGA data (Fig. 4) that as expected, ceramic yield decreases with the increase in the amount of the complex.

Powder X-ray diffraction (Powder XRD). Powder XRD of palladium containing $\mathrm{SiCN}$ ceramics was carried out to confirm the amorphous nature of the matrix as well as the presence of the metallic phase. The reflection pattern of the cubic phase of palladium was totally absent in the diffractograms and reflections characteristic of the hexagonal phase of $\mathrm{Pd}_{2} \mathrm{Si}$ were observed. Powder XRD data of dipalladium silicide $\left(\mathrm{Pd}_{2} \mathrm{Si}\right)$ were simulated from the single crystal XRD data ${ }^{51}$ and were used as reference for the interpretation of powder XRD results (Fig. 5). The peaks at $2 \theta$ values of $38.1^{\circ}, 41.4^{\circ}, 42.4^{\circ}$ and $48.5^{\circ}$ in $\mathrm{Pd} 20-$ FC ( $8 \mathrm{wt} \%$ Pd) can be assigned to the reflections of (201), (210), (300) and (110) planes of hexagonal $\mathrm{Pd}_{2} \mathrm{Si}$. With the decrease in the amount of metal within the support, only the most intense peaks at $38.1^{\circ}, 41.4^{\circ}$ and $42.4^{\circ}$ can be seen in the diffractograms of all the $\mathrm{Pd}_{2} \mathrm{Si} @ \mathrm{SiCN}$ composites synthesized. Reflection patterns corresponding to other silicide phases ( $\mathrm{PdSi}$ and $\left.\mathrm{Pd}_{3} \mathrm{Si}\right)$, as evident from the phase diagram of the $\mathrm{Pd}-\mathrm{Si}$ system, ${ }^{52}$ are not found in powder XRD. Reflections at $20.8^{\circ}, 26.8^{\circ}$ and $36.5^{\circ}$ may be assigned to quartz. The formation of quartz may arise because of the exposure of thermosets to air during their transfer to a furnace for pyrolysis. Palladium rich $\beta-\mathrm{Pd}_{2} \mathrm{Si}$ is stable in the temperature regime of $1090-1404{ }^{\circ} \mathrm{C}$ above which it melts congruently and below $1090^{\circ} \mathrm{C}$ it transforms to its silicon rich

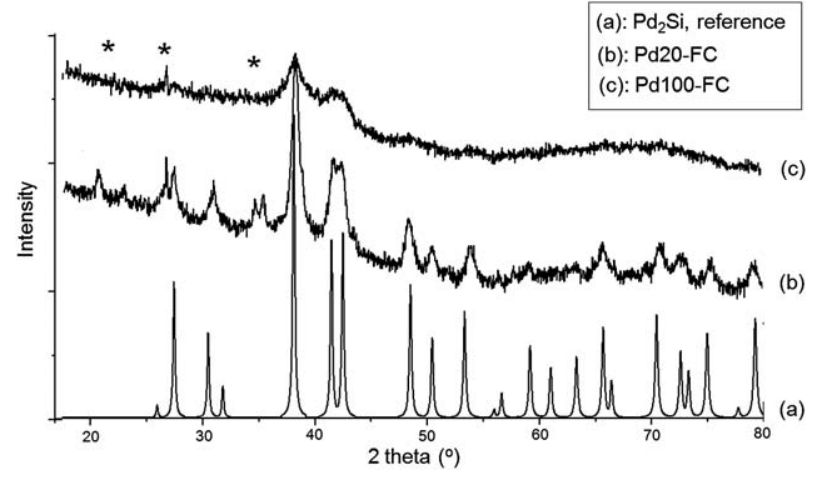

Fig. 5 Powder XRD of ceramics (pyrolysed at $1100^{\circ} \mathrm{C}$ under nitrogen atmosphere) in comparison to the simulated powder XRD pattern of hexagonal $\mathrm{Pd}_{2} \mathrm{Si}$, the most intense peaks at $38.1^{\circ}, 41.4^{\circ}$ and $42.4^{\circ}$ correspond to (201), (210) and (300) planes. ${ }^{*}$ : reflections at $20.8^{\circ}, 26.8^{\circ}$ and $36.5^{\circ}$ may be assigned to quartz.

polymorph $\left(\alpha-\mathrm{Pd}_{2} \mathrm{Si}\right)$. The formation of the hexagonal $\mathrm{Pd}_{2} \mathrm{Si}$ phase could be the result of the interaction of amorphous $\mathrm{SiCN}$ with palladium at a pyrolysis temperature of $1100{ }^{\circ} \mathrm{C}$. In our previous report, ${ }^{32}$ formation of the metallic phase instead of metal silicide phases was confirmed by powder XRD and solid state copper NMR studies.

In fact, formation of copper silicide requires much higher amount of loaded copper $(>80 \mathrm{wt} \%)$ within the system ${ }^{53}$ which is very unlikely at a maximal copper loading of $13.7 \%$ in the $\mathrm{Cu} @ \mathrm{SiCN}$ system..
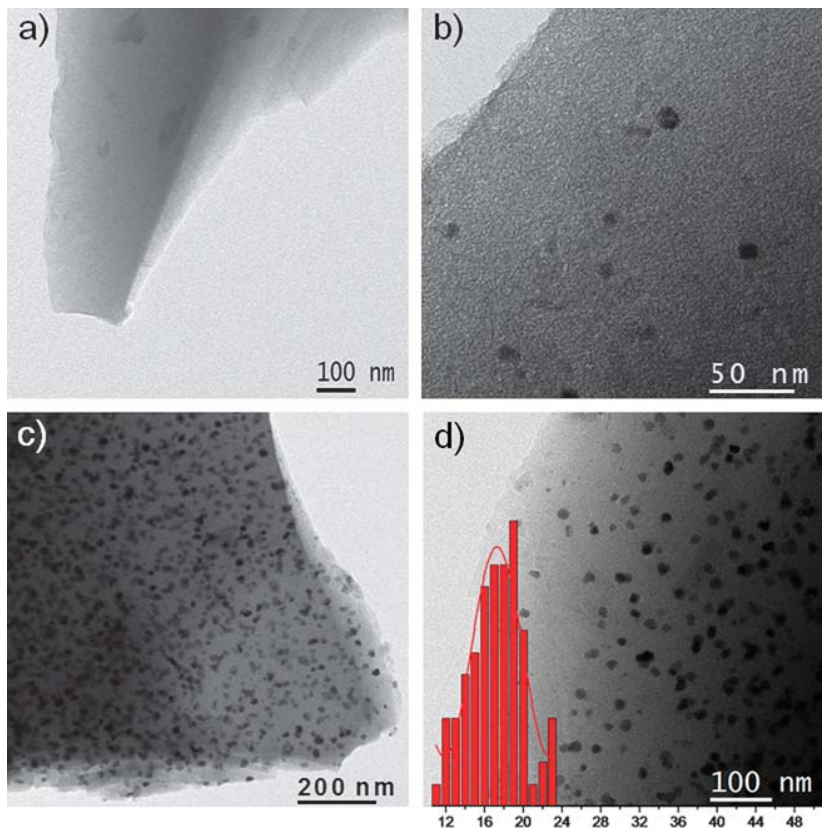

Fig. 6 TEM micrographs of ceramic materials. (a) $\mathrm{SiCN}$ ceramic without palladium loading does not show any particles; (b) lower loading of palladium $(0.2 \mathrm{wt} \%$, Pd1000-FC) decreases the density of particles keeping their size in the same regime; (c) $\mathrm{Pd}_{2} \mathrm{Si}$ particles uniformly distributed over Pd20-FC ( $8 \mathrm{wt} \% \mathrm{Pd}$ ); (d) dipalladium silicide nanoparticles in $\mathrm{Pd} 20-\mathrm{FC}$ with particles size distribution. 

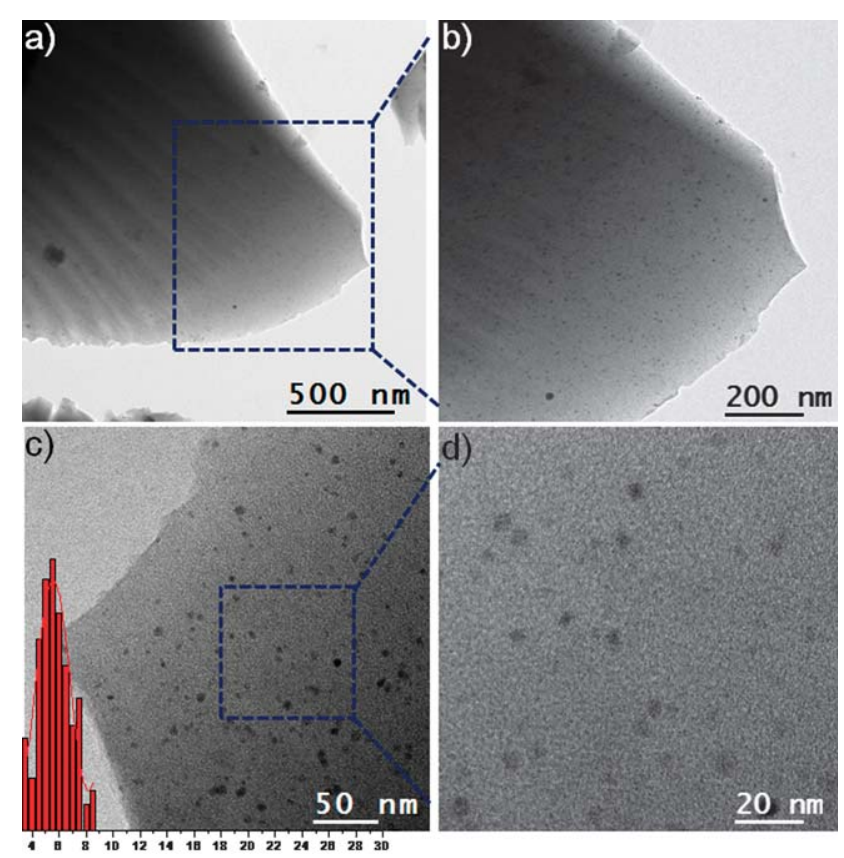

Fig. 7 (a-d) TEM micrographs of Pd20-FC synthesized in hexane $(15 \mathrm{~mL})$; a uniform distribution of palladium silicide particles over the ceramic has been shown at different magnifications in figures (a) and (b) while figure (c) shows palladium silicide particles ( 4 to $6 \mathrm{~nm}$ ) with size distribution.

TEM investigations. TEM micrographs of the samples provide further insight into the microstructure of the supported palladium silicide nanoparticles (Fig. 6 and 7). The size of the particles generated on the ceramic support depends on the cross-linking step. The two samples pyrolysed under same conditions but using different solvents (in the cross-linking step) generate particles with different sizes. On the other hand, samples with different loadings of palladium but cross-linked under identical conditions give the same size of the nanoparticles (Fig. 6b and d). Thus, size can be controlled in terms of the nature of the solvent used for the mixing of the palladium complex with polysilazane. Since the palladium complex is highly soluble in THF, only a small amount of the solvent $(5 \mathrm{~mL})$ was enough for its complete dissolution. A much faster exothermic reaction takes place upon the addition of palladium complex solution to the polymer resulting in an immediate cross-linking along with the chemical modification of polysilazane. The metal modified polymer upon its pyrolysis generates palladium silicide particles with an average size of $18 \mathrm{~nm}$ (Fig. 6d) with a uniform distribution over the surface (Fig. 6c). In the case where hexane was used as solvent, palladium complex requires a relatively large amount of solvent ( $15 \mathrm{~mL}$ as compared to $5 \mathrm{~mL}$ of THF in the first approach) for its dissolution. The nanoalloy particles generated in this case are 5-6 nm in size (Fig. 7c) and are homogeneously distributed over the support with the population density comparable to those synthesized using THF as solvent (Fig. 7a-d). When the amount of THF was increased to $15 \mathrm{~mL}$, the cross-linking took place with a much slower rate but the particles generated were within the same size regime $(\sim 18 \mathrm{~nm})$. Thus it is the nature of the solvent and not the extent of dilution which controls the size of the particles formed. It is evident from Fig. 5a that without the addition of palladium complex to the polymer no palladium silicide particles are generated over the ceramic support. The population density of the particles formed depends upon the amount of metal complex reacted with the polymer (Fig. 6b) keeping their size the same $(16-18 \mathrm{~nm})$.

Catalytic studies. In the case of palladium based nanoalloys, both unsupported ${ }^{54}$ and supported $\mathrm{Pd}-\mathrm{Ga}^{55,56}$ have recently been reported as efficient selective catalysts for semihydrogenation of alkynes. The alloys of palladium with silicon are worth mentioning here in this regard as these materials show excellent catalytic activities for many reactions of industrial importance. ${ }^{57-59}$ According to Bartok and co-workers ${ }^{60}$ semihydrogenation of alkynes over $\mathrm{Pd}-\mathrm{Si}$ alloy provides better selectivity in comparison to the $\mathrm{Pd}-\mathrm{Ge}$ and pure palladium catalysts. Baiker et al. found high conversion and selectivity for $\mathrm{Pd}_{81} \mathrm{Si}_{19}$ alloy in the semihydrogenation of propargyl alcohol and phenylacetylene in supercritical carbon dioxide. ${ }^{61,62}$ Palladium silicide phases generated as a result of metal support interactions in the $\mathrm{Pd} / \mathrm{SiO}_{2}$ system have been reported to be selective catalysts in semihydrogenation of phenylacetylene to styrene ${ }^{63}$ and for neopentane isomerization. ${ }^{64-66}$ The group of Massardier reported on the catalytic activity of palladium silicides containing $\mathrm{Pd} / \mathrm{SiC}$ catalysts for methane total oxidation. ${ }^{67}$ A promising feature of palladium silicides is their chemical and electrochemical stability ${ }^{68}$ which makes them ideal candidates as anode materials for fuel cell applications. ${ }^{69,70}$

Catalytic hydrogenation of ketones. Catalytic hydrogenation of aromatic ketones to various products (Fig. 8a) was investigated using the $\mathrm{Pd}_{2} \mathrm{Si} @ \mathrm{SiCN}$ catalyst system. All the catalysts with
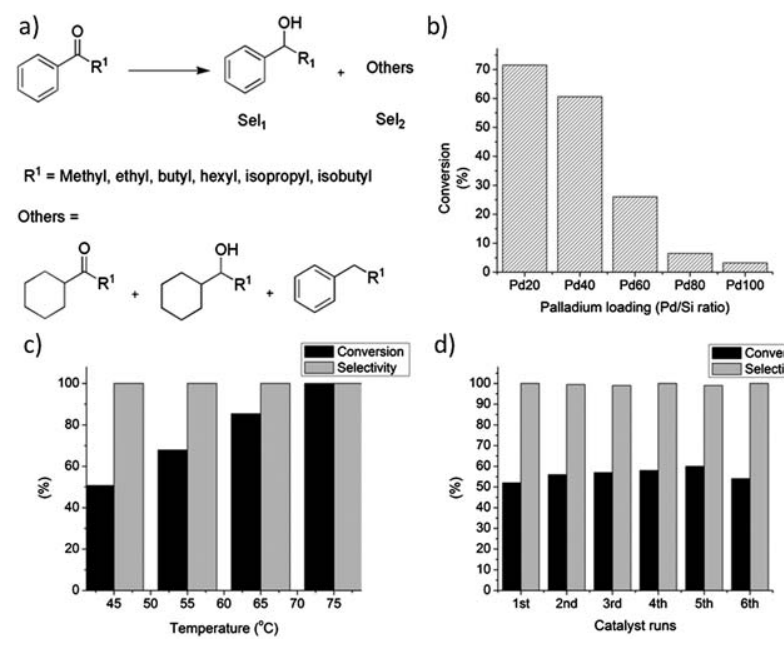

Fig. 8 (a) Schematic representation of catalytic hydrogenation of ketones to different products; (b) hydrogenation of acetophenone ( $2 \mathrm{mmol}$ ) with $60 \mathrm{mg}$ of catalyst at $75^{\circ} \mathrm{C}$ under 20 bar hydrogen for 24 hours. The conversion decreases with decrease in the amount of palladium contained by the ceramics; (c) hydrogenation of acetophenone ( $2 \mathrm{mmol}$ ) using Pd20-FC (120 mg) under 20 bar hydrogen pressure for 24 hours. The conversion increases with temperature keeping the selectivity constant; (d) hydrogenation of acetophenone $(2 \mathrm{mmol})$ with the catalyst Pd20-FC (60 mg) under 20 bar hydrogen pressure at $75^{\circ} \mathrm{C}$ for 24 hours. The figure shows reusability of the catalyst up to six catalyst runs. 
Table 2 Hydrogenation of ketones using the catalyst Pd20-FC ( $8 \mathrm{wt} \%$ Pd) at 85 and $50{ }^{\circ} \mathrm{C} ; 1 \mathrm{mmol}$ of substrate, $0.4 \mathrm{~mL}$ toluene and $60 \mathrm{mg}$ of catalyst were used under 40 bar hydrogen pressure

\begin{tabular}{|c|c|c|c|c|}
\hline \multirow[b]{2}{*}{ Substrate } & \multicolumn{2}{|l|}{$85^{\circ} \mathrm{C}$} & \multicolumn{2}{|l|}{$50{ }^{\circ} \mathrm{C}$} \\
\hline & Conversion $^{a}$ & $\begin{array}{l}\mathrm{Sel}_{1} / \\
\mathrm{Sel}_{2}^{b}\end{array}$ & Conversion & $\begin{array}{l}\mathrm{Sel}_{1} / \\
\mathrm{Sel}_{2}\end{array}$ \\
\hline Acetophenone & 100 & $99 / 1$ & 46 & $99 / 1$ \\
\hline Propiophenone & 100 & $99 / 1$ & 48 & $99 / 1$ \\
\hline Valerophenone & 100 & $99 / 1$ & 42 & $99 / 1$ \\
\hline Heptanophenone & 98 & $99 / 1$ & 33 & $99 / 1$ \\
\hline 2-Methyl-1-propiophenone & 100 & $99 / 1$ & 11 & $99 / 1$ \\
\hline 2,2-Dimethyl-1- & 93 & $99 / 1$ & 4 & $99 / 1$ \\
\hline
\end{tabular}

propiophenone

${ }^{a}$ Conversion in $\mathrm{mol} \%$ units. ${ }^{b} \mathrm{Sel}_{1}$ and $\mathrm{Sel}_{2}$ denote selectivity to alcoholic and other products respectively.

a palladium loading ranging from 2 to $8 \mathrm{wt} \%$ (Pd100-FC to Pd20-FC) show selective hydrogenation of ketones to alcoholic products. Pd20-FC ( $8 \mathrm{wt} \% \mathrm{Pd}$ ) shows higher performance (Fig. 8b) than other ceramics (Pd40-FC, Pd60-FC, Pd80-FC and $\mathrm{Pd} 100-\mathrm{FC})$ and was selected for further studies. The conversion increases both with the increase in catalyst amount and temperature (Fig. 8c) but selectivity remains the same. Alkyl phenyl ketones with alkyl chain length ranging from 1 to 7 carbon atoms (acetophenone to heptanophenone) and those having branching at alpha carbon (2-methyl-1-propiophenone and 2,2-dimethyl-1-propiophenone) were applied in the investigations. Catalytic studies were performed both at 85 and $50{ }^{\circ} \mathrm{C}$ under 40 bar hydrogen pressure for 24 hours. It was found that at $85^{\circ} \mathrm{C}$ both the conversion and the selectivity to alcohol were above $95 \%$. At $50{ }^{\circ} \mathrm{C}$, however, the conversion decreases both with the increase in alkyl chain length and its branching at alpha carbon. The selectivity again remains above $99 \%$ to the alcoholic product (Table 2). The catalyst does not show any deactivation after a reaction time of 75 hours. Recycling of the catalyst was studied at $50 \%$ conversion by adjusting the amount of catalyst added. After 24 hours, the reaction was stopped and the catalyst was separated by centrifugation and dried under vacuum at $120^{\circ} \mathrm{C}$ for 6 hours. A slight increase in conversion was observed after first run and no loss of activity was observed over six consecutive catalyst runs (Fig. 8d).

\section{Conclusions}

$\mathrm{Pd}_{2} \mathrm{Si}$ nanoparticles supported by a polymer derived $\mathrm{SiCN}$ matrix have been synthesized following a molecular approach making use of an aminopyridinato palladium complex. The complex cross-links the polysilazane via hydrogen evolution increasing the ceramic yield. Moreover it chemically modifies the precursor by the transfer of palladium to its amido nitrogen atoms. The metal modified polymer, upon its pyrolysis at $1100{ }^{\circ} \mathrm{C}$, provides dipalladium silicide nanoparticles. The size of the particles formed depends upon the solvent used and is independent of the amount of loaded metal. Higher metal loading results in a higher density of particles. Catalysts show selective formation of alcohols from the hydrogenation of ketones. Overall conversion of the reaction increases with catalyst amount and temperature keeping the selectivity constant. A decrease in activity was observed with an increase in alkyl chain length and branching at alpha carbon of the ketone.

\section{Acknowledgements}

The authors are grateful to Justus Hermannsdörfer for TEM analysis, Kathrin Inzenhofer for TGA studies and Dr Wolfgang Milius for powder XRD measurements. Financial support from Deutsche Forschungsgemeinschaft (DFG, SPP 1181) is gratefully acknowledged. M. Zaheer is thankful to Higher Education Commission of Pakistan (HEC) and Deutscher Akademischer Austausch Dienst (DAAD) for the fellowship.

\section{Notes and references}

1 R. Ferrando, J. Jellinek and R. L. Johnston, Chem. Rev., 2008, 108, 845-910.

2 Q. J. Sun, Y. A. Wang, L. S. Li, D. Wang, T. Zhu, J. Xu, C. Yang and Y. Li, Nat. Photonics, 2007, 1, 717-722.

3 S. Coe, W.-K. Woo, M. Bawendi and V. Bulovic, Nature, 2002, 420, 800-803.

4 M. Wuttig and N. Yamada, Nat. Mater., 2007, 6, 824-832.

5 D. Alloyeau, C. Ricolleau, C. Mottet, T. Oikawa, C. Langlois, Y. L. Bouar, N. Braidy and A. Loiseau, Nat. Mater., 2009, 8, 940946.

6 T. C. Harman, P. J. Taylor, M. P. Walsh and B. E. LaForge, Science, 2002, 297, 2229-2232.

7 B. Lim, M. Jiang, P. H. C. Camargo, E. C. Cho, J. Tao, X. Lu, Y. Zhu and Y. Xia, Science, 2009, 324, 1302-1305.

8 A. Kowal, M. Li, M. Shao, K. Sasaki, M. B. Vulkmirovik, J. Zhang, N. S. Marinkovic, P. Liu, A. I. Frenkel and R. R. Adzic, Nat. Mater., 2009, 8, 325-330.

9 V. R. Stamenkovic, B. S. Mun, M. Arenz, K. J. J. Mayrhofer, C. A. Lucas, G. Wang, P. N. Ross and N. M. Markovic, Nat. Mater., 2007, 6, 241-247.

10 F. Maroun, F. Ozanam, O. M. Magnussen and R. J. Behm, Science, 2001, 293, 1811-1814.

11 J. Greeley, I. E. L. Stephens, A. S. Bondarenko, T. P. Johansson, H. A. Hansen, T. F. Jaramillo, J. Rossmeisl, I. Chorkendorff and J. K. Nørskov, Nat. Chem., 2009, 1, 552-556.

12 X. Ji, K. T. Lee, R. Holden, L. Zhang, J. Zhang, G. A. Botton, M. Couillard and L. F. Nazar, Nat. Chem., 2010, 2, 286-293.

13 L. Kesavan, R. Tiruvalam, M. H. Ab Rahim, M. I. bin Saiman, D. I. Enache, R. L. Jenkins, N. Dimitratos, J. A. Lopez-Sanchez, S. H. Taylor, D. W. Knight, C. J. Kiely and G. J. Hutchings, Science, 2011, 331, 195-199.

14 D. I. Enache, J. K. Edwards, P. Landon, B. S. Espriu, A. F. Carley, A. A. Herzing, M. Watanabe, C. J. Kiely, D. W. Knight and G. J. Hutchings, Science, 2006, 311, 362-365.

15 S. Alayoglu, A. U. Nielkar, M. Mavrikakis and B. Eichhorn, Nat. Mater., 2008, 7, 333-338.

16 M. Schrinner, S. Proch, Y. Mei, R. Kempe, N. Miyajima and M. Ballauff, Adv. Mater., 2008, 20, 1928-1933.

17 F. Besenbacher, I. Chorkendorff, B. S. Clausen, B. Hammer, A. M. Molenbroek, J. K. Nørskov and I. Stensgaard, Science, 1998, 279, 1913-1915.

18 G. W. Huber, J. W. Shabaker and J. A. Dumesic, Science, 2003, 300, 2075-2077.

19 P. Colombo, R. Riedel, G. D. Soraru and H.-J. Kleebe, in Polymer Derived Ceramics: from Nanostructure to Applications, DEstech Publications, Inc., Pennsylvania, USA, 2010.

20 H.-J. Kleebe, H. Störmer, S. Trassl and G. Ziegler, Appl. Organomet. Chem., 2001, 15, 858-866.

21 R. Riedel, H.-J. Kleebe, H. Schönfelder and F. Aldinger, Nature, 1995, 374, 526-528.

22 W. Weibelzahl, G. Motz, D. Suttor and G. Ziegler, Key Eng. Mater., 1999, 161-163, 111-114.

23 G. Thurn, J. Canel, J. Bill and F. Aldinger, J. Eur. Ceram. Soc., 1999, 19, 2317-2323.

24 G. Motz, Adv. Sci. Technol., 2006, 50, 24-30.

25 A. Izumi and K. Oda, Thin Solid Films, 2006, 501, 195-197. 
26 H. Hoche, D. Allebrandt, R. Riedel and C. Fasel, Plasma Processes Polym., 2009, 6, S649-S654.

27 H.-Y. Ryu and R. Raj, J. Am. Ceram. Soc., 2007, 90, 295-297.

28 S. I. Andronenko, A. Leo, I. Stiharu and S. K. Misra, Appl. Magn. Reson., 2010, 39, 347-356.

29 I. K. Sung, Christian, M. Mitchell, D. Kim and P. Kenis, Adv. Funct. Mater., 2005, 15, 1336-1342.

30 M. Kamperman, A. Burns, R. Weissgraeber, N. V. Vegten, S. C. Warren, S. M. Gruner, A. Baiker and U. Wiesner, Nano Lett., 2009, 9, 2756-2762.

31 Christian, M. Mitchell, D.-P. Kim and P. J. A. Kenis, J. Catal., 2006, 241, 235-242.

32 G. Glatz, T. Schmalz, T. Kraus, F. Haarmann, G. Motz and R. Kempe, Chem.-Eur. J., 2010, 16, 4231-4238.

33 X. Yan, X. Cheng, C. Li, R. Hauser and R. Riedel, Mater. Sci. Forum, 2007, 546-549, 2269-2272.

34 A. Saha, S. R. Shah and R. Raj, J. Mater. Res., 2003, 18, 2549-2551.

35 R. Hauser, A. Francis, R. Theismann and R. Riedel, J. Mater. Sci., 2008, 43, 2042-2049.

36 D. Seyferth, H. Lang, C. A. Sobon, J. Borm, H. J. Tracy and N. Bryson, J. Inorg. Organomet. Polym., 1992, 2, 59-77.

37 M. J. MacLachlan, M. Ginzburg, N. Coombs, T. W. Coyle, N. P. Raju, J. E. Greeden, G. A. Ozin and I. Manners, Science, 2000, 287, 1460-1463.

38 M. Ginzburg, M. J. MacLachlan, S. M. Yang, N. Coombs, T. W. Coyle, N. P. Raju, J. E. Greedan, R. H. Herber, G. A. Ozin and I. Manners, J. Am. Chem. Soc., 2002, 124, 2625-2639.

39 B.-Z. Tang, R. Peterson, D. A. Foucher, A. Lough, N. Coombs, R. Sodhi and I. Manners, J. Chem. Soc., Chem. Commun., 1993, 523-525.

40 R. Peterson, D. A. Foucher, B. Tang, A. Lough, N. P. Raju, J. E. Greedan and I. Manners, Chem. Mater., 1995, 7, 2045-2053.

41 T. Schmalz, T. Kraus, M. Guenthner, C. Liebscher, U. Glatzel, R. Kempe and G. Motz, Carbon, 2011, 49, 3065-3072.

42 (a) R. Kempe, Eur. J. Inorg. Chem., 2003, 791-803; (b) G. Glatz, S. Demeshko, G. Motz and R. Kempe, Eur. J. Inorg. Chem., 2009, 1385-1392; (c) S. Deeken, G. Motz and R. Kempe, Z. Anorg. Allg. Chem., 2007, 633, 320-325; (d) A. Spannenberg, A. Tillack, P. Arndt, R. Kirmse and R. Kempe, Polyhedron, 1998, 17, 845-850; (e) S. Deeken, S. Proch, E. Casini, H. F. Braun, C. Mechtler, C. Marschner, G. Motz and R. Kempe, Inorg. Chem., 2006, 45, 1871-1879; (f) G. Glatz, G. Motz and R. Kempe, Z. Anorg. Allg. Chem., 2008, 634, 2897-2902.

43 H. Okamoto, J. Phase Equilib. Diffus., 2007, 28, 231-232.

44 R. K. Joshi, M. Yoshimura, K. Tanaka, K. Ueda, A. Kumar and N. Ramgir, J. Phys. Chem. C, 2008, 112, 13901-13904.

45 R. Kempe and P. Arndt, Inorg. Chem., 1996, 35, 2644-2649.
46 J. Wiedermann, K. Mereiter and K. Kirchner, J. Mol. Catal. A: Chem., 2006, 257, 67-72.

47 A. Spannenberg, P. Arndt and R. Kempe, Angew. Chem., Int. Ed., 1998, 37, 832-835.

48 D. Seyferth, H. Lang, C. A. Sobon, J. Borm, H. J. Tracy and N. Bryson, J. Inorg. Organomet. Polym., 1992, 2, 59-77.

49 N. S. Choong Kwet Yive, R. J. P. Corriu, D. Leclercq, P. H. Mutin and A. Vioux, Chem. Mater., 1992, 4, 141-146.

50 A. Francis, E. Ionescu, C. Fasel and R. Riedel, Inorg. Chem., 2009, 48, 10078-10083.

51 A. Nylund, Acta Chem. Scand., 1966, 20, 2381-2386.

52 C. Boxi and T. B. Massalski, J. Phase Equilib., 1991, 12, 349-356.

53 R. W. Olensinski and G. J. Abbaschian, Bull. Alloy Phase Diagrams, 1986, 7, 170-178.

54 M. Armbrüster, G. Wowsnick, M. Friedrich, M. Heggen and R. C. Gil, J. Am. Chem. Soc., 2011, 133, 9112-9118.

55 A. Ota, M. Arbrüster, M. Behrens, D. Rosenthal, M. Friedrich, I. Kasatkin, F. Girgsdies, W. Zhang, R. Wagner and R. Schlögl, J. Phys. Chem. C, 2011, 115, 1368-1374.

56 L. Shao, W. Zhang, M. Armbrüster, D. Teschner, F. Girgsdies, B. Zhang, O. Timpe, M. Friedrich, R. Schlögl and D. S. Su, Angew. Chem., Int. Ed., 2011, 50, 1-6.

57 A. N. Correia, L. H. Mascaro, S. A. S. Machado and L. A. Avaca, J. Braz. Chem. Soc., 1999, 10, 478-482.

58 A. Molnar, G. V. Smith and M. Bartok, Adv. Catal., 1989, 36, 329383.

59 H. Walter, G. Roewer and K. Bohmhammel, J. Chem. Soc., Faraday Trans., 1996, 92, 4605-4608.

60 A. Molnar, G. V. Smith and M. Bartok, J. Catal., 1986, 101, 67-72.

61 R. Tschan, R. Wandler, M. S. Schneider, M. Burganer, M. M. Schubert and A. Baiker, Appl. Catal., A, 2002, 223, 173-185.

62 R. Tschan, R. Wandeler, M. S. Schneider, M. M. Schubert and A. Baiker, J. Catal., 2001, 204, 219-229.

63 J. Panpranot, K. Phandinthong, T. Sirikajorn, M. Arai and P. Praserthdam, J. Mol. Catal. A: Chem., 2007, 261, 29-35.

64 W. Juszczyk, Z, Karpinski, D. Lomot and J. Pielaszek, J. Catal., 2003, 220, 299-308.

65 W. Juszczyk, Z. Z. Karpinski, J. Pielaszek and J. W. Sobczak, New J. Chem., 1993, 17, 573-576.

66 W. Juszczyk and Z. Karpinski, J. Catal., 1989, 117, 519-532.

67 Ch. Methivier, B. Beguin, M. Brun, J. Massardier and J. C. Bertolini, J. Catal., 1998, 173, 374-382.

68 A. K. Vijh and G. Belanger, J. Mater. Sci. Lett., 1995, 14, 982-984.

69 A. K. Vijh, G. Belanger and R. Jacques, J. Mater. Sci. Lett., 1993, 12, 113-115.

70 N. V. Vlasenko and N. I. Ilchenko, React. Kinet. Catal. Lett., 1988, 36, 189-193. 